\title{
BUILDING KNOWLEDGE AND KNOWERS IN WRITING RETREATS: TOWARDS DEVELOPING THE FIELD OF HIGHER EDUCATION TEACHING AND LEARNING
}

\author{
C. Winberg* \\ e-mail:WinbergC@cput.ac.za

\section{Jacobs} \\ Centre for Teaching and Learning \\ Stellenbosch University \\ Stellenbosch, South Africa \\ e-mail: jacobsc@sun.ac.za
}

\section{K. Wolff*}

e-mail:wolff.ke@gmail.com

*Work-integrated Learning Research Unit

Cape Peninsula University of Technology

Cape Town, South Africa

\section{ABSTRACT}

Writing for publication is essential for disseminating research findings, sharing initiatives and innovations with others, and developing the knowledge base of intellectual fields. This study explores the role of writing retreats in building knowledge and knowers in the field of Higher Education Studies, specifically within the area of higher education pedagogy. We conceptually frame our research with Legitimation Code Theory (Maton 2014) in order to analyse the different ways in which participants in writing retreats orientate themselves to the social practice of writing for publication and the knowledge base of higher education pedagogy. The data comprise participants' feedback on writing retreats, collected from surveys and focus group interviews at two universities (a teaching-intensive university and a research-intensive university), and supplementary institutional data on retreat participants and their writing achievements. By examining the organising principles of the writing retreats in terms of how they build knowledge and knowers, we make explicit the knowledge-building practices that underpin successful writing retreats and the orientations towards these practices that are productive for potential authors.

Keywords: Higher Education Studies, writing retreats, knowledge-building practices, South Africa, pedagogy, Legitimation Code Theory

\section{INTRODUCTION}

As a relatively new field, Higher Education Studies needs research, dissemination and 
development. Writing journal articles on teaching and learning research presents an opportunity for university teachers to develop their ideas and develop the field. Writing for publication is foundational to scholarship, yet is seldom explicitly taught; as a result, many beginning (and experienced) academics struggle to write and struggle to cope with the emotions, such as selfdoubt, that such difficulties stir up (Murray 2012). This is particularly the case when writing in a new intellectual field. As university teachers are primarily affiliated to their home disciplines, it is to be expected that they would experience difficulties when writing about higher education pedagogy. Academics across the world, as in South Africa, face increasing pressure to publish; indeed, for many their jobs depend on this. The growing emphasis on research outputs has often targeted groups less familiar with academic research practices, such as teachers in vocational or professional programmes (Turner, Brown and Edwards-Jones 2014). For many academic women, making space in their daily lives to write is an ongoing struggle (Grant and Knowles 2000), thus writing about their teaching practice is an opportunity to engage in scholarly publication. Academic staff are increasingly expected to demonstrate their commitment to teaching and learning, which can be made evident through an educational publication. Writing retreats generally offer university teachers the opportunity to take a more scholarly approach to their teaching, and to obtain peer feedback and support in the process of preparing their research findings for publication.

\section{Research objectives and focus}

Published journal articles are highly valued by universities. Writing retreats - although primarily intended to enable academic writers to improve their public output - also often support developing researchers by engaging them in communities of research practice. The larger objective of this study is to make visible the underpinning principles of writing for publication in educational journals that are often tacit, and to identify the conditions for successful participation in writing retreats. The research questions that guided this study are:

1. What forms of knowledge underpin successful publication in higher education pedagogy?

2. What social dispositions support writing for publication in the company of other writers, and how can those characteristics be fostered?

\section{BRIEF OVERVIEW OF THE LITERATURE}

Despite the current emphasis on publishing to enhance individual and institutional profiles, there is little in the literature on the principles of writing for publication (Morss and Murray 
2001), nor is there much research that explains how to improve quality and productivity in the field of higher education pedagogy specifically (Van Schalkwyk, Cilliers, Adendorff, Cattell and Herman 2013). Some promising research findings suggest that writing retreats have the potential to help academics to produce outputs of a high quality by creating dedicated writing time in a context of strong collegial support (Murray and Newton 2009). The literature on scholarly writing proposes that writers' retreats represent a valuable professional development opportunity that can potentially support more productive patterns of writing (Moore 2003). Research studies show that writing is a highly fluid process, requiring the constructive feedback of 'critical friends' and on-going readjustments to the writing focus (Cameron, Nairn and Higgins 2009).

Becoming a skilled writer brings intellectual and social rewards, but the extended nature and difficulty of this process create unique challenges. Bruning and Horn (2000) propose a number of conditions that are important in the development of writing: (1) nurturing functional beliefs about writing; (2) fostering engagement using authentic writing tasks; (3) providing a supportive context for writing; and (4) creating a positive emotional environment. Grant and Knowles (2000) find that developing the identity of the 'writing subject' is important, and that this identity can be nurtured through supportive writing retreats. The use of authentic writing tasks, including a targeted journal for the writing, has been shown to have a strong positive impact on participants' ability to achieve publication outputs (Murray 2011). Writing retreats are only successful to the extent that they provide skilled peer support for writing; in other words, more knowledgeable writers to assist and support novice writers (Murray and Cunningham 2011) and the provision of a 'safe space' for writing development (Grant 2006).

The literature discusses strategies for attending to the emotions of writing, as well as developing writing 'know-how' and a stronger sense of identity as a writer. It is argued that addressing all three aspects of writing - emotions, know-how and identity - helps demystify the academic writing process and helps novices on their journey to becoming published authors (Cameron, Nairn and Higgins 2009). For novice writers, a carefully structured and facilitated writers' retreat is an effective method to support writing outcomes (Murray and Cunningham 2011). When planning a writing retreat for novice writers, it is important that writers are wellprepared for the retreat, that they have research findings to write from (in the form of a research report, for example), that the retreat is conducted in ways that blend structured input, supportive peer review and free time for writing, and that there is follow-up to a writers' retreat, such as identifying writing mentors and creating writers' groups (Murray and Moore 2006). For experienced writers, MacLeod, Steckley and Murray (2012) argue that a retreat does more than 
simply provide time to write; it is a model of 'strategic engagement' - a way of regularly producing high quality publications while continuing to meet other professional demands.

The literature has tended to emphasise the affective and attitudinal aspects of writing and the concomitant need for emotional and collegial support in writing retreats. The literature also regards writing as 'generic', rather than writing within a discipline or field that is underpinned by a knowledge base to which the writer is contributing. What is absent from the literature is an understanding of the knowledge practices that underpin successful writing or how writing retreats might enable or foster the emergence of knowledge-building practices. The intention of writing for publication is to build knowledge in a field, yet the literature on the practices of writing for publication has tended to neglect the importance of the authors' knowledge contribution. The range of conceptual frameworks that have been used to study writing communities are aligned with the affective and attitudinal focus of much of the literature. For example, Van Schalkwyk et al. (2013) use Mesirow’s ‘transformative learning' to conceptually frame their work; Bruning and Horn (2000) draw on motivational theory; Murray and Cunningham (2011) adapt Gardiner's researcher development framework; while Grant (2006) and Grant and Knowles (2000) position their work within feminist studies. MacLeod, Steckley and Murray (2012) and Murray and Newton (2009) draw on 'Containment Theory', an approach to strategic thinking that is commonly used in understanding time management and strategic planning in the world of organisational development.

\section{THEORETICAL FRAMEWORK}

Because we understand writing retreats as opportunities to build knowledge and knowers in higher education pedagogy, we conceptually frame our research with Legitimation Code Theory (LCT), a framework that has been widely used to study knowledge and knowers (e.g., Maton 2014) and knowledge-building (e.g. Maton, Hood and Shay 2016). LCT offers an explanation of the underlying structures of different forms of knowledge as well as the ways in which knowers orientate themselves to that knowledge. By examining the organising principles of the writing retreats, we can make more explicit the knowledge that underpins successful writing for publication, as well as the orientations towards this knowledge that are useful for potential authors. LCT offers many 'tools' for the analysis of knowledge practices; in this article we draw on the dimension of Specialization (Maton 2014) for analysing the ways in which successful writing is underpinned by specialist knowledge and writers are characterised by particular dispositions. Specialization is based on the understanding that 'practices and beliefs are about or oriented towards something and by someone' (Maton 2014, 29). Maton argues that 
it is possible to distinguish between the 'epistemic relations between practices' and the 'social relations between practices' (in this case the practice of scholarly writing). Epistemic and social relations highlight what can be legitimately claimed as knowledge and who can claim to be a legitimate knower. These relations work together to reveal the organising principles underpinning practices, such as writing for publication.

Epistemic relations in scholarly writing about teaching and learning are underpinned by educational theory and research methods, so these would be 'legitimate' forms of knowledge in this context; social relations in writing for publication include familiarity with the publishing practices of education journals, and these would identify a 'legitimate' knower. It would be expected that different participants at retreats might have stronger or weaker levels of knowledge about educational theory and research methods, as well as more or less appropriate dispositions towards writing for publication. The stronger or weaker epistemic and social relations could be identified along a continuum of educational knowledge and a continuum of more or less appropriate dispositions to writing, as in Table 1:

Table 1: Epistemic and social relations in writing for publication

\begin{tabular}{|c|c|c|c|}
\hline \multirow{2}{*}{$\begin{array}{l}\text { Epistemic } \\
\text { relations }\end{array}$} & \multirow{2}{*}{$\begin{array}{c}\text { Stronger } \\
\uparrow \\
\text { Weaker }\end{array}$} & \multirow{2}{*}{$\begin{array}{l}\text { Knowledge of educational } \\
\text { theories and research } \\
\text { methods }\end{array}$} & $\begin{array}{l}\text { Knowledge of or learning about appropriate } \\
\text { theoretical frameworks and methodologies for } \\
\text { educational research. }\end{array}$ \\
\hline & & & $\begin{array}{l}\text { Having little or no knowledge of educational theory } \\
\text { or research methods (whatever the knowledge of } \\
\text { other fields). }\end{array}$ \\
\hline \multirow{2}{*}{$\begin{array}{l}\text { Social } \\
\text { relations }\end{array}$} & \multirow{2}{*}{$\overbrace{}^{\text {Stronger }}$} & \multirow{2}{*}{$\begin{array}{l}\text { Dispositions of 'knowers' } \\
\text { (or potential authors) }\end{array}$} & $\begin{array}{l}\text { Participating in a community of writers (e.g., access } \\
\text { appropriate networks, engage in peer review, } \\
\text { approaching editors, understanding journal } \\
\text { practices) }\end{array}$ \\
\hline & & & $\begin{array}{l}\text { Attending the writing retreat for purposes other than } \\
\text { participation in an educational writing community, or } \\
\text { misunderstanding what participation in a community } \\
\text { of writers entails. }\end{array}$ \\
\hline
\end{tabular}

\section{CONTEXTUALISING THE STUDY}

\section{Context 1: The teaching-intensive university}

The DVC: Teaching and Learning at the Cape Peninsula University of Technology awards annual grants, known as the 'Research and Innovation Fund for Teaching and Learning' (RIFTAL), to academic staff for educational research. As part of the award, grant-holders are invited to attend a writing retreat where they are assisted in writing up their research findings for possible publication. The first writing retreats were largely unstructured. Typically, the writers set goals on arrival, were partnered with a 'critical friend' and concluded the retreat with 
a reflection on what they had achieved. In response to participant feedback requesting more support, subsequent retreats were considerably more structured, for example, with presentations by facilitators or visiting experts, or focussed around a single theoretical framework. Over the course of nine writing retreats, one can see a shift from unstructured to highly-structured and then towards semi-structured writing retreats. It is difficult to estimate how productive the writing retreats have been. The institution's research outputs, as audited by the DHET, show that over the period 2012-2015, the 79 researchers who attended nine writing retreats (some attended several retreats) produced approximately 50 journal articles on higher education teaching and learning. From the participant feedback received, some who attended the retreat advanced their Masters or doctoral studies, while others developed a deeper understanding of what it might mean to become a teaching and learning scholar.

\section{Context 2: The research-intensive university}

Stellenbosch University, through its Centre for Teaching and Learning, offers writing retreat opportunities to lecturers twice a year. The writing retreats are intended to help participants to learn from each other about the process of writing in an atmosphere of trust and safety, create a multidisciplinary community of writers, explore links between teaching, research, writing and scholarship, and have a productive working experience in which each participant commits to a specific writing goal. For the purposes of this study, five writing retreats were investigated during 2014-2016. There are usually two streams of writers at the writing retreats: one focused on writing educational articles for publication in scholarly journals, the other focused on writing proposals to access the Fund for Innovation and Research in Learning and Teaching (FIRLT). However, there have been participants who have also used the retreats to engage in other forms of writing, such as educational book chapters, educational conference presentations, teaching portfolios, curriculum renewal documents, as well as parts of $\mathrm{PhD}$ dissertations. During the two-year period of this study, 72 lecturers participated in the writing retreats (with some attending more than one retreat). The output for this two-year period was 30 published journal articles, 17 successful FIRLT proposals, 9 papers-in-progress (from the last retreat in May 2016) and 18 other outputs.

The structure of the programmes of the five writing retreats changed over the reporting period. In 2014 the retreats had a fairly tightly structured programme, with facilitated sessions, structured presentations and inputs from experienced educational researchers. In response to feedback from participants this was changed at the end of 2014 to an unstructured format, where participants were allowed to write in their own time and spaces, and there were no input 
sessions. At the end of 2015 and into 2016 there was yet another change to the writing retreat programme, to a semi-structured model, where all participants were required to attend a compulsory 'sit-down-and-write' session each morning, in a common venue with no internet connections, as well as a scheduled 'fireside chat' each evening with a 'critical friend' to give feedback on the day's writing.

\section{A methodology for researching writing retreats}

\section{Data collection}

The data for this study were drawn from the writing retreats offered by the two institutions. The sources of data included: writing retreat documents (such attendance lists, application forms, writing retreat programmes, writing retreat outputs, etc.), statistical data on the number of participants, their writing purposes and their outputs, written feedback from individual writing retreat participants, and focus group interviews with participants. The data collected are summarised in Table 2.

Table 2: Data collection overview

\begin{tabular}{|c|c|c|c|c|c|}
\hline Institution & $\begin{array}{l}\text { Period of } \\
\text { study }\end{array}$ & $\begin{array}{l}\text { Number of } \\
\text { retreats }\end{array}$ & $\begin{array}{l}\text { Number of } \\
\text { unique } \\
\text { participants }\end{array}$ & $\begin{array}{l}\text { Nature of writing } \\
\text { retreats }\end{array}$ & Data sources \\
\hline $\mathrm{C}$ & $\begin{array}{l}\text { Oct } 2011 \\
\text { to Apr } \\
2016\end{array}$ & 9 & 79 & $\begin{array}{l}\text { Unstructured } \rightarrow \\
\text { Highly structured } \rightarrow \\
\text { Semi-structured }\end{array}$ & \multirow{2}{*}{$\begin{array}{l}\text { Attendance lists and } \\
\text { application forms } \\
\text { Participant feedback forms } \\
\text { Recorded focus group/ } \\
\text { reflective discussions } \\
\text { Institutional publication audit }\end{array}$} \\
\hline$S$ & $\begin{array}{l}\text { Jan } 2014 \\
\text { to May } \\
2016\end{array}$ & 5 & 72 & $\begin{array}{l}\text { Structured } \rightarrow \\
\text { Unstructured } \rightarrow \\
\text { Semi-structured }\end{array}$ & \\
\hline
\end{tabular}

\section{Ethical considerations}

Ethics clearance for this study was obtained from the Cape Peninsula University of Technology and permission was obtained to conduct the study at both the Cape Peninsula University of Technology and Stellenbosch University. While the institutions are named, neither the writing retreat participants, nor their departments or disciplines are named for purposes of confidentiality. Participant data is attributed by institution (i.e., C or S) and writing retreat number (e.g., CWR1). Any quotation data that might identify a participant or academic department were removed.

\section{Data analysis methods}

In order to understand how specialist knowledge and participants' dispositions contribute to successful writing retreats, broad descriptors of educational knowledge-building and writers’ 
dispositions were initially used to code the data. In the second round of coding these relations were differentiated in terms of educational theory and educational research methods, as well as differentiating between participants' engagement in the ad hoc academic writing community of the immediate writing retreat and their engagement in a broader research community through publishing in academic journals.

\section{FINDINGS AND DISCUSSION: KNOWLEDGE AND KNOWERS IN WRITING RETREATS}

In this section we discuss the findings in the separate categories of the knowledge underpinning the practice of writing as well as participants' dispositions towards writing (understanding that the separation is analytical) before we consider some of the connections between knowledge building and writing dispositions in more detail.

\section{The knowledge underpinning writing practices}

Participants brought different kinds of educational knowledge to the task of writing about teaching and learning. Some new writers understood educational research as describing practice and not as theorising practice or subjecting it to rigorous research methodologies. Some writing participants came to the writing retreat with theoretical knowledge and had research findings that had been produced through educational research design and methods. Participants with a stronger theoretical understanding of higher education pedagogy came to the retreat with the intention that their article-in-progress should contribute to theory-building. A participant explained that her concern in the retreat was to 'connect to other strains of educational research and ... refocus on bigger conceptions' (SWR5). Several participants had come to writing retreats with little in the way of educational theory to underpin their writing, but were there to obtain such knowledge. These participants appreciated 'being made aware of the theoretical frameworks' (CWR7) and were in the process of developing stronger epistemic relations towards the practice of writing:

... my second aim was trying to expand a bit of a framework for a teaching and learning publication and if I hadn't sat and spoken to [a facilitator] one of the evenings, I wouldn't have been able to link what was happening with my research to the theory. And that's what I've always missed, is that I think I'm creative and quite interesting in class, but - and I know instinctively that there is something in theory - but to find that connection - I haven't got enough experience or skill to know what needs to go with that (SWR5).

While most participants had come to the retreat with a draft paper or research data, some participants had come to the retreat for assistance with analytical methods, 'need[ing] more on how to analyse data according to research paradigms' (CWR9) or 'want[ing] to work with 
software packages such as your Atlas TI and SPSS ...' (CWR7).

Many participants had come to the retreat with theoretical and research knowledge of other disciplines, and some used the time and opportunity for purposes other than that of writing up educational research, such as the participant who provided the following feedback on a writing retreat; for example:

I managed to write a theoretical paper which I've already presented at an international conference [in my own discipline] (SWR5).

Some participants recommended that the facilitators include disciplines other than education in the retreat, suggesting that colleagues 'exchange [their] writing before the retreat ... and having people in the same field as [their] own' (SWR5). In a few cases, it seemed that writers had come to the retreat expecting a 'writing service' to be provided by the facilitators and saw no need to shift their own epistemic relations towards their educational writing project; for example:

I would have appreciated more assistance with the 'how to write for education' as I know what I want to say but there is a way to write for education (CWR4).

A number of participants had attended the retreat for purposes other than writing up educational research. One participant (a subject librarian) saw the retreat as an opportunity to engage with academic staff in order 'to improve and align library instruction and assessment with classroom education methods' (CWR8). Others attended because they were developing a new curriculum, developing research proposals, or furthering their own Master's or doctoral study. While many of these purposes could lead to productive teaching and learning or research outcomes, there were a few participants who misunderstood the purpose of the retreat. One participant thought the retreat would involve training in post-graduate supervision.

While it is unlikely that fundamental educational knowledge could be built in the short time of the writing retreat, there was a growing awareness that participants were entering a new field. One writer, experienced in writing in her own discipline but new to educational writing, expressed this as:

all the parts of the jigsaw that come together ... and only right at the end you see ... oh this is my picture ... it's still a bit vague but hopefully it will become clearer' (CWR7).

For the others, knowledge building occurred across a number of writing retreats, rather than in a single epiphany:

... at a previous ... writing retreat that I've been to, there was quite a lot of sessions on background theory that was done and if I hadn't had that previous retreat, I wouldn't have been able to jump in here. So I was thinking yesterday, if everybody's here for the first time ... or writing, you know, the first time - they're probably thrown in the deep end. So maybe it's a 
good idea to have this kind of space and then also break away sessions for people who want some more theory (SWR5).

\section{Writing in/for a community of scholars}

Most participants attend writing retreats to engage with other writers. Our data included feedback on different ways of working with educational knowledge: group discussions, coauthor discussions, critical friends, peer review, facilitator feedback and expert input. Writers were engaged in both informal writing collaborations, comprising interactions between peers (e.g. feedback from a 'critical friend') and specialised academic communities of practice (e.g. facilitators helping an author to select an appropriate journal). Writers who had successfully published could assert themselves as legitimate knowers in the field of publication in educational journals because they had knowledge of publishing, editorial boards, journal requirements, etc. Some writers described their need to write within a 'safe space':

What was quite comfortable for me was having a writing partner and being able to talk to and to also spend a lot of time ... constructing prose. That's what made it quite productive from my point of view (SWR5).

There were also those who did not find the writing retreat a 'comfortable' space, but who nevertheless valued peer support in the 'struggle' to write, and who learned 'from similar struggles' (CWR4). Others felt the need for more 'guidance', to the extent of having facilitators 'show what they researched and how they used [a theory]' (CWR5). Writing for an educational journal is not easy - one participant claimed that 'it's much harder than writing in science' (SWR5) - and several participants pointed out it requires discipline and dedication:

... We have to be here, we must write ... not search for readings but actually write (SWR5).

Not everyone who had come to the writing retreat wanted to engage with other writers, but wanted the time and space to work on a project that was not necessarily an educational one. There were also participants who came to socialise, whose interest was in the dinner conversations' (CWR7), while others took advantage of the presence of colleagues to discuss departmental 'business' (CWR9). There were also participants who 'felt excluded and wondered if [the writing retreat] was only for a selected group of people' (CWR5), as well as those who had perhaps underestimated the difficulty of writing for publication and had no desire to engage in the struggle to write. These interactions (or non-interactions) were coded as weaker social relations towards scholarly writing.

A growing awareness emerged, particularly amongst novice writers, that a wider community of writers existed and that the writing retreat potentially provided access to this 
more formal community. Participants expressed this in terms of understanding a wider 'audience' (comprising journal editors, reviewers and expert readers) for their work, as the following feedback indicates:

... the fact that we had this input from experienced facilitators was very valuable ... they showed us what it is like to write for a journal. I'll start with [Facilitator 1] who showed us what it is to work with genre ... and that there are even certain type of articles and knowing that you are writing for specific journals can save time and prevent rejections .... [Facilitator 2] shared her journal checklist with us and showed us rhetorical moves to shape the article .... We were told about the 'hooks' and the rhetorical moves whether it is for the abstract or the 'hooks' for the introduction. [Facilitator 3] shared the idea of the funnel for the literature ... and the claims that speak to theory (CWR7).

We noted shifts in participants' attitudes towards writing as they were inducted into the practices of the writing retreat and became aware that they were writing for an academic community of practice. This involved something of an identity shift, as the following participant explained:

I think this group - working together - and it just adds a little bit more towards that part of your identity (SWR5).

The participant below expresses his growing awareness that educational writing often uses the first person and tends to avoid passive sentence constructions not merely as a convention, but as a way of taking responsibility for one’s research:

I learnt also the possibility to use 'I' as to mean writing responsibly in research. This was an added value since I knew only writing by using third person in research (CWR4).

Table 3 summarises the findings thus far. The table has two main sections. The first column of each section explains the various forms of the educational knowledge underpinning writing in this study, as well as the attitudes towards writing that were evident. The second column of each section contains the indicators for the values, and the third column presents illustrative quotes from the empirical data.

Table 3: Knowledge and knowers in writing retreats

\begin{tabular}{|l|l|l||l|l|l|}
\hline \multicolumn{2}{|l||}{ Types of knowledge } & Knowers' dispositions & \multicolumn{2}{l|}{} \\
\hline Concept & Indicators & $\begin{array}{l}\text { Example of supporting } \\
\text { data }\end{array}$ & Concept & Indicators & $\begin{array}{l}\text { Example of } \\
\text { supporting data }\end{array}$ \\
\hline $\begin{array}{l}\text { Knowledge of } \\
\text { educational } \\
\text { theory }\end{array}$ & $\begin{array}{l}\text { Knowledge of, } \\
\text { or learning } \\
\text { about, } \\
\text { appropriate } \\
\text { theoretical } \\
\text { frameworks }\end{array}$ & $\begin{array}{l}\text { 'It gets you thinking ... } \\
\text { maybe to be more critical } \\
\text { of what you are doing. } \\
\text { What am I actually saying? } \\
\text { Or how does this connect } \\
\text { to other strands of } \\
\text { educational research?' }\end{array}$ & $\begin{array}{l}\text { Engagement } \\
\text { with the } \\
\text { informal } \\
\text { community of } \\
\text { the writing } \\
\text { retreat }\end{array}$ & $\begin{array}{l}\text { Active } \\
\text { engagement } \\
\text { with retreat } \\
\text { participants }\end{array}$ & $\begin{array}{l}\text { fact that we're } \\
\text { here, but also the } \\
\text { people that are } \\
\text { here ...' (SWR5) }\end{array}$ \\
\hline
\end{tabular}




\begin{tabular}{|c|c|c|c|c|c|}
\hline \multicolumn{3}{|c|}{ Types of knowledge } & \multicolumn{3}{|c|}{ Knowers' dispositions } \\
\hline \multirow[t]{3}{*}{ Concept } & Indicators & $\begin{array}{l}\text { Example of supporting } \\
\text { data }\end{array}$ & Concept & Indicators & $\begin{array}{l}\text { Example of } \\
\text { supporting data }\end{array}$ \\
\hline & & (SWR5). & & & \\
\hline & $\begin{array}{l}\text { No/little } \\
\text { knowledge of } \\
\text { educational } \\
\text { theory }\end{array}$ & $\begin{array}{l}\text { '... [in future retreats] the } \\
\text { content must be practical } \\
\text { and not as theoretical as it } \\
\text { was this time' (CWR5). }\end{array}$ & & $\begin{array}{l}\text { Participation for } \\
\text { other purposes }\end{array}$ & $\begin{array}{l}\text { '... when the team } \\
\text { gets together ... we } \\
\text { tend to talk } \\
\text { business' (CWR9). }\end{array}$ \\
\hline \multirow[t]{2}{*}{$\begin{array}{l}\text { Knowledge of } \\
\text { educational } \\
\text { research } \\
\text { methods }\end{array}$} & $\begin{array}{l}\text { Knowledge of } \\
\text { / learning } \\
\text { about } \\
\text { educational } \\
\text { research } \\
\text { methods }\end{array}$ & $\begin{array}{l}\text { 'I think my colleagues are } \\
\text { also excited about working } \\
\text { with the data we have } \\
\text { generated ...' (CWR9) }\end{array}$ & \multirow[t]{2}{*}{\begin{tabular}{|l} 
Engagement \\
with formal \\
(publishing) \\
communities \\
of educational \\
academic \\
writing
\end{tabular}} & $\begin{array}{l}\text { Active } \\
\text { engagement } \\
\text { with formal } \\
\text { educational } \\
\text { academic } \\
\text { publishing } \\
\text { communities }\end{array}$ & $\begin{array}{l}\text {... the fact that we } \\
\text { had this input from } \\
\text { experienced } \\
\text { facilitators was } \\
\text { very valuable ... } \\
\text { they showed us } \\
\text { what it is like to } \\
\text { write for a journal' } \\
\text { (CWR7). }\end{array}$ \\
\hline & $\begin{array}{l}\text { Little } \\
\text { knowledge or } \\
\text { experience of } \\
\text { educational } \\
\text { research }\end{array}$ & $\begin{array}{l}\text { 'Put people who have had } \\
\text { educational research } \\
\text { experience at the same } \\
\text { table so the rest of us } \\
\text { don't feel like idiots when } \\
\text { we don't really understand } \\
\text { what they are talking } \\
\text { about' (CWR2). }\end{array}$ & & $\begin{array}{l}\text { Little } \\
\text { engagement } \\
\text { with formal } \\
\text { educational } \\
\text { academic } \\
\text { publishing }\end{array}$ & $\begin{array}{l}\text { 'Our group had } \\
\text { more discussions } \\
\text { than writing or } \\
\text { giving feedback ...' } \\
\text { (CWR7) }\end{array}$ \\
\hline
\end{tabular}

\section{Varieties of knowledge and knowers in writing retreats}

Table 3 summarises how writing retreat participants engaged with educational knowledge and educational writing communities. We have shown that understandings of educational theory and research methodology (or openness to learning more about educational theory and methods) and dispositions towards collaborative writing and towards the world of educational publication varied amongst participants. Some of these variants are discussed below.

\section{Writing in other disciplines and other forms of non-participation}

Non-participant writers attended the writing retreat for the purpose of writing a paper in their own (non-educational) discipline, and did not want to discuss educational theory or methods with participants at the retreat. There were also non-participants who attended the retreat without much knowledge of educational theory or research, and did not wish to acquire such knowledge; thus their interactions with retreat participants were not appropriate to the writing retreat. (We note that it is also possible to write for some discipline-based education journals without educational theory, using a research methodology from another discipline).

\section{Aspiring writers}

Many participants' attendance at the writing retreat was aspirational; such participants were keen to engage with others about their writing project, but were not sufficiently well-grounded 
in educational theory or methodology to write up their educational innovation or teaching practice for publication. The following comment shows how engagement in the writing retreat, helped to clarify thinking (even though it might not have been very productive in terms of actual writing):

Our group had more discussions than writing or giving feedback ... but it was meaningful to me because in that process we exchanged articles and so on ... my purpose has become more clear ... about what I want to do with my article (CWR7).

This category is an important one in the context of higher education teaching and learning, both because it is a new field and because many academics are interested in writing about and sharing their innovative teaching with wider audiences. Our study suggests that appropriate participation with peers and facilitators in the writing retreat is a means of accessing the theoretical and methodological knowledge necessary for publication. Engagement in the informal or ad hoc community of the writing retreat is predominantly 'affective', but can give rise to more 'cognitive' engagement with educational theory and research methodologies, as well as to more expert forms engagement with larger academic communities. The following participant explains how he accessed theoretical and methodology knowledge:

... new things were learned ... for me it was the fact the different headings should talk to each other for example your research methodology should talk to the findings and the findings to the research methodology ... and also regarding the literature review the analysis must talk to the literature review and vice versa ... (CWR7).

The study data provides several examples of how engagement with a hierarchy of 'knowers' on the retreat (peers, critical friends, critical readers, more able others, facilitators and experts) enabled participants' access to educational knowledge and writing practices; this is something that participants 'don't have ... in [their own departmental] space’ (SWR5). Participants explained that engagement with facilitators or expert presenters enabled them 'to see further' (CWR7):

... about the CoP [Community of Practice] - I think for us, this is not our normal way of thinking, in terms of education, so it's good to be here so that you can also bounce ideas off and get the authors' names that you can go and look at and see their slant, so it does inform, so it's not just the fact that we're here, but also the people that are here ... (SWR5).

\section{Non-participant educational writers}

This group was not common in the data as it describes educational writers who have come to the retreat to focus on a piece of educational writing without engaging with other writers or wider journal communities. The following quotation describes a participant who had a particular project that he wanted to focus on, without peer support or interaction: 
I personally didn't need [the writing retreat] to be structured in the way that it was. I mean, I've got enough guilt and anxiety to drive my work ethic and get my stuff done, you know. So - I think there were very specific objectives and I was - you know, I've got a history of getting things done (SWR5).

\section{Expert and progressing writers}

Many retreat participants who attended the writing retreat did so for the purpose of writing up educational research findings in an educational publication (or learning how to do so) in a context of collaboration and support. Such participants, even those who were seasoned writers, valued the opportunity to write in the company of other writers:

... you are in your own little world and you think you are doing well, but in the discussion, now you hear something from engineering that [a colleague] shares, or from other fields. It all of a sudden gets you thinking about, maybe to be more critical of what you are doing. What am I actually saying? Or how does this connect to other strands of educational research? (SRW5).

For developing writers, the writing retreat provided both access to educational knowledge and induction into a writing community, this was expressed by some participants in term of an identity shift:

I developed a voice ... I come away with ... a set of tools ... steps and processes .... My academic identity as a researcher is something I think I'm starting to grow into (CWR7).

Table 4 summarises the second set of findings with regard to varieties of knowledge and knowers. These findings point to a reciprocal relationship between epistemic and social relations in the practice of writing for publication.

Table 4: Connections between educational knowledge and writing dispositions

\begin{tabular}{|l|l|l|l|}
\hline & $\begin{array}{l}\text { Having little or no knowledge of } \\
\text { educational theory or research } \\
\text { methods (whatever the } \\
\text { knowledge of other fields). }\end{array}$ & $\begin{array}{l}\text { Drawing on, contributing } \\
\text { to, or learning about } \\
\text { educational theories }\end{array}$ & $\begin{array}{l}\text { Drawing on, contributing to, or } \\
\text { learning about educational } \\
\text { research methods }\end{array}$ \\
\hline Non-participation & $\begin{array}{l}\text { The peer reviews made the } \\
\text { situation worse because we had to } \\
\text { provide input on research areas } \\
\text { that I was not familiar with, and this } \\
\text { took a lot of time that I did not have } \\
\text { (CWR4). }\end{array}$ & $\begin{array}{l}\text { I experienced that I ... got } \\
\text { into focus, got working and } \\
\text { (SWR5). }\end{array}$ & $\begin{array}{l}\text { I came with this bunch of papers, } \\
\text { and it gave me the space to look } \\
\text { at my research and find the } \\
\text { themes in the papers to support } \\
\text { what I wanted to do. So it can also } \\
\text { be exploring. It can be that } \\
\text { literature review. So I think } \\
\text { reading is an important aspect to } \\
\text { feed into your writing (SWR5) }\end{array}$ \\
\hline $\begin{array}{l}\text { Engagement with } \\
\text { the (informal) } \\
\text { writing retreat } \\
\text { educational } \\
\text { research } \\
\text { community of } \\
\text { practice }\end{array}$ & $\begin{array}{l}\text { I'll be able to see further by } \\
\text { standing on the shoulders of gurus } \\
\text {... (CWR7) }\end{array}$ & $\begin{array}{l}\text { I enjoyed the conceptual } \\
\text { framework and how [the } \\
\text { facilitator] made it very } \\
\text { practical and make it easy } \\
\text { for me to draw up the } \\
\text { conceptual framework that I I } \\
\text { would like to use for my } \\
\text { study (CWR7). }\end{array}$ & $\begin{array}{l}\text { Even if you get published you can } \\
\text { still improve on your writing ... } \\
\text { there are things that you might } \\
\text { overlook in your writing. You need } \\
\text { a session like this where people } \\
\text { can find out what is valuable about } \\
\text { their writing ... (CWR7). }\end{array}$ \\
\hline
\end{tabular}




\begin{tabular}{|l|l|l|l|}
\hline & $\begin{array}{l}\text { Having little or no knowledge of } \\
\text { educational theory or research } \\
\text { methods (whatever the } \\
\text { knowledge of other fields). }\end{array}$ & $\begin{array}{l}\text { Drawing on, contributing } \\
\text { to, or learning about } \\
\text { educational theories }\end{array}$ & $\begin{array}{l}\text { Drawing on, contributing to, or } \\
\text { learning about educational } \\
\text { research methods }\end{array}$ \\
\hline $\begin{array}{l}\text { Engagement with } \\
\text { a (formal) wider } \\
\text { educational } \\
\text { research } \\
\text { community of } \\
\text { practice }\end{array}$ & $\begin{array}{l}\text { clear ... about what I want to do } \\
\text { with my article (CWR7). }\end{array}$ & $\begin{array}{l}\ldots \text { I've got that habit which I } \\
\text { didn't have before and that } \\
\text { came from attending writing } \\
\text { retreats (SWR5) }\end{array}$ & $\begin{array}{l}\text { I developed a voice ... I come with ... a set of tools ... } \\
\text { steps and processes ... My } \\
\text { academic identity as a researcher } \\
\text { is something I think I'm starting to } \\
\text { grow into (CWR7). }\end{array}$ \\
\hline
\end{tabular}

\section{CONCLUSION: 'FINDING NARNIA'}

The literature on writing retreats and collective writing has emphasised the affective and generic aspects of writing, in particular the importance of writing in a 'safe space'. Our data similarly shows the importance of social relations, such as the support of the writing community for the affective dimension of writing:

You know we should accept that it's not only an intellectual process, it's also an affective emotional process, and people who have writer's block, for example ... how to assist each other in the processing of those emotional aspects of writing? (SWR5).

What the literature has not interrogated is why social relations in the practice of writing are so significant. Our findings show that interaction with a hierarchy of knowers in the 'safe space' of the writing retreat enables participants' access to educational knowledge, as well as to the wider community of higher education scholars. In the study we tracked participants' educational knowledge-building practices as well as how they started to take on a more scholarly educational identity. Participation in writing retreats can induct participants into the practices of writing for publication through scaffolded processes of building both knowledge and knowers.

In their feedback many participants expressed the understanding that writing was enabled by the 'space' of the retreat. Participants offered interpretations of the 'space' that went beyond its physical location and the time away from the demands of work and family. Participants spoke about affordances of the writing retreat in terms of 'head space', 'safe space' and 'productive space'. Participants described the space as 'a very unique environment' (CWR7), 'the right kind of space' (CWR7), a 'positive feedback environment' (SWR2):

... there is a very participatory spirit here ... the structures and linkages and the 'so what' element that enables us to write persuasively and obviously the very open and enabling environment, the submersion and immersion in a writing environment ... (CWR7).

The fact, this is on the guilt side ... that I know that somebody is paying for me to use this space, so it's such a beautiful space and that this had been done for me, even though I can see that there are other benefits, that ... obliges me to make the best use of this time possible (SWR5). 
Not all writing retreats are the same; they fulfil different purposes over time for different participants, depending on their individual needs and areas of focus. Some retreats are more specifically intended for novice educational researchers (as has been the case with most of the retreats reported on in this study), but there are other kinds of retreats in which experts assemble to work on a group project or paper. So for some attendees, the space functioned as 'rocket fuel' (CWR7) to get a writing project started:

... from my own personal experience, there's less avoidance when you come to the writing retreat whereas at home you can get away with avoiding, procrastinating, ... it's easier a bit for me here, and also the fact that other people are writing with you, so everyone's in the same boat (SRW5).

The space can be an extremely productive space for those who are prepared to spend dedicated time on their writing, even if the end result is not a ready-for-submission academic paper, as the following participant explains:

... usually in the rush of teaching I notice something, I want to research it, I can just, just manage to create a repository of ideas for myself. I need this space to come and sit and research. Look through papers, start with an initial idea without wanting to - feeling pressured - that I must now deliver something formally written at the end ... (SWR5).

While the literature has correctly identified the importance of the social, it has not adequately conceptualised the role of social relations in enabling epistemic access and has underestimated the importance of a knowledge contribution in writing for publication. This article thus contributes to the literature on writing for publication by problematizing the social relations towards writing for publication, and by further defining the dispositions towards the immediate writing community of the retreat and the larger community of teaching and learning scholars.

The implications of our findings suggest that the space of the writing retreat is one in which both epistemic relations and social relations can be fostered. Flexibility in the structure of the retreat is recommended and would be dependent on the needs of participants. The writing retreat structure should provide opportunities for the feedback of critical friends or critical readers, but also for theory-building with more expert others. Ideally, much of the work involved in developing educational theory and research should be done prior to acceptance of participants for the retreat, while the more experienced knowers on the retreat itself, because of its specific focus on writing for publication, are well placed to induct new writers in the field into the larger community of publishers, reviewers and journals. One of the participants described his particular experience of the writing 'space' as finding 'Narnia':

... so I want to reiterate that strictness but also the defending of this, what you call Narnia, space. It does something. It creates a bit more value and just adds a little bit more focus ... so it was very good (SWR5). 
The Narnia reference is insightful, implying that the retreat is more than a physical space; it is a creative space that 'does something' to participants. The writing retreat is inhabited by a community of writers, who bring their different understandings, experiences and practices to the task of writing. The 'space' (emphasised by the Narnia metaphor) serves to take writers out of their everyday worlds of teaching and learning into a world of educational ideas, theories, research methods, publishing and reviewers.

\section{REFERENCES}

Bruning, Roger and Christy Horn. 2000. Developing motivation to write. Educational Psychologist 35(1): 25-37. doi:10.1207/S15326985EP3501_4

Cameron, Jenny, Karen Nairn and Jane Higgins. 2009. Demystifying academic writing: Reflections on emotions, know-how and academic identity. Journal of Geography in Higher Education 33(2): 269-284. doi:10.1080/03098260902734943

Grant, Barbara M. 2006. Writing in the company of other women: Exceeding the boundaries. Studies in Higher Education 31(4): 483-495. doi: 10.1080/03075070600800624

Grant, Barbara and Sally Knowles. 2000. Flights of imagination: Academic women be(com)ing writers. International Journal for Academic Development 5(1): 6-19. doi:10.1080/136014400410060

MacLeod, Iain, Laura Steckley and Rowena Murray. 2012. Time is not enough: Promoting strategic engagement with writing for publication. Studies in Higher Education 37(6): 641-654. doi: 10.1080/03075079.2010.527934

Maton, Karl. 2014. Knowledge and knowers: Towards a realist sociology of education. London: Routledge.

Maton, Karl and Rainbow Chen. 2016. LCT in qualitative research: creating a translation device for studying constructivist pedagogy. In Knowledge building: Educational studies in Legitimation Code Theory, ed. Karl Maton, Sue Hood and Suellen Shay, 27-48. London: Routledge.

Maton, Karl, Sue Hood and Suellen Shay. (Eds.). 2016. Knowledge building: Educational studies in Legitimation Code Theory. London: Routledge

Moore, Sarah. 2003. Writers' retreats for academics: Exploring and increasing the motivation to write. Journal of Further and Higher Education 27(3): 333-342. doi:10.1080/0309877032000098734

Morss, Kate and Rowena Murray. 2001. Researching academic writing within a structured programme: Insights and outcomes. Studies in Higher Education 26(1): 35-52. doi:10.1080/03075070020030706

Murray, Rowena. 2012. Developing a community of research practice. British Educational Research Journal 38(5): 783-800

Murray, Rowena and Everarda Cunningham. 2011. Managing researcher development: 'Drastic transition’? Studies in Higher Education 36(7): 831-845. doi: 10.1080/03075079.2010.482204

Murray, Rowena and Sarah Moore. 2006. The handbook of academic writing: A fresh approach. Maidenhead, Open University Press and McGraw-Hill

Murray, Rowena and Mary Newton. 2009. Writing retreat as structured intervention: Margin or mainstream? Higher Education Research \& Development 28(5): 541-553. doi:10.1080/07294360903154126

Turner, Rebecca, Tony Brown and Andrew Edwards-Jones. 2014. 'Writing my first academic article feels like dancing around naked': Research development for higher education lecturers working in further education colleges. International Journal for Academic Development 19(2): 87-98. doi:10.1080/1360144X.2013.792729 
Van Schalkwyk, Susan, Francois Cilliers, Hanelie Adendorff, Karin Cattell and Nicoline Herman. 2013. Journeys of growth towards the professional learning of academics: Understanding the role of educational development. International Journal for Academic Development 18(2): 139-151. 